\title{
Illuminating urban street (u)topias
}

Lesley Murray, School of Applied Social Science, Watson Building, University of Brighton, Brighton BN19PH. L.Murray@brighton.ac.uk

Susan Robertson, School of Architecture and Design, Mithras House, University of Brighton, Brighton BN2 4AT S.Robertson@brighton.ac.uk

\begin{abstract}
A utopian vision of the city is often bright, well-lit, and conversely darkness and night are more often associated with dystopia. This paper uses an ethnographic study of night-time in a busy street space in the middle of a south coast UK city in order to demonstrate the application of 'utopia as method' (Levitas 2013), or rather utopia as mobile method in understanding justice and injustice in urban space. In doing so, we suggest the possibilities of urban mobile space, arguing that 'utopia as method' originates in Lefebvre's (1991) work on the possibilities that arise from the seemingly impossible imaginings of urban transformation. We use what are considered to be distinct approaches to photography: 'ethnographic' and 'expressive' in demonstrating this.

Photography tells a story of the lighting of the space in illuminating the street in particular ways and making visible aspects that otherwise may go unnoticed. We draw from the boundaries, of photography (and therefore light), of method, and of urban space, looking to the 'territorial edges' (Sennett 2006) for Lefebvre's possibilities.
\end{abstract}

\section{Introduction}

Light is often associated with utopia. Light and mobility are conceptually bound in representing progress, but at the same time in revealing injustice. Variations in lightness and darkness produce mobilities, immobilities and mobile spaces, yet it is an underdeveloped aspect of mobility studies. Light, at all spatial scales, tells multiple stories that are often hidden. As Edensor $(2017,82)$ argues, there is 'unevenness in brightness, quality and purpose' of illumination in cities; and the distribution of lighting reproduces inequalities. Light is unevenly distributed by the workings of institutions, urbanists, business and state through time and space. Edensor illustrates the ways in which darkness is associated with deviancy, with authorities attempting to 'control movement and particular practices in nocturnal space' through surveillance $(2017,82)$. At the micro level, darkness decelerates and immobilises - people and vehicles move more slowly in the dark; moving in darkness requires stealth and is therefore often perceived as a subversive act. Light, on the other hand, affords a more informed movement and symbolises freedom. A 'utopian' vision of the city is often bright, well-lit, and, conversely, darkness and night are more often associated with 'dystopia'. However this static conceptualisation of light and dark reflects the limitations of a dualistic reading of utopia and dystopia. Indeed landscape geographer Kenneth Olwig $(2002,52)$ suggests we need to 'move beyond' this dualism, '... beyond modernism's utopianism and postmodernism's dystopianism to a topianism that recognises that human beings [...] consciously and unconsciously create places'. Olwig is here disputing the relevance of utopia to place.

The first question we seek to address here is therefore whether we need to move beyond 'utopia' in making sense of justice and injustice in mobile urban space. We do so by engaging with 'utopia as method', which is most often associated with Ruth Levitas (2013) and her book of that title. In it, whilst acknowledging the critiques of utopian thinking, as modernist 'irrelevant fantasy', Levitas directs us to a way of thinking that promises to challenge the 'concrete instantiation' of inequality and injustice. For Levitas, 'overt suspicion of utopia is accompanied by hopeful, visionary openness to the future' (2013, xiii). Arguably, any attempt to uncover the potential for justice should begin with such a vision. And in placing this potential, we turn to the work of urban 
sociologist Henri Lefebvre, whose own 'utopia as method' sought to elucidate the 'possibilities' of urban space. Then we seek to mobilise the concept of utopia as method and, in doing so, contribute to debates on mobility justice. For although Sheller $(2018,39)$ argues that existing theories of spatial justice fail 'to foreground the unjust mobilities that they depend on and reproduce', we suggest that the mobilisation of these theories can produce particular insights on injustice. Sheller takes issue with the analyses of Harvey, Lefebvre and Soja in that they adopt a short view of time that obscures histories of injustices that are rooted in movement and its control. She suggests that focusing on the city makes such global struggles invisible, and disconnects the coerced mobilities of enslavement, colonialism, and imperialism from the broader discussion of mobility rights and spatial justice. However, a multi-scalar and connected approach to the city, which considers borders, both within and without, as porous can re-connect these global struggles to the scale of the city.

Second, we set out to illustrate the utility of 'utopia as method' in providing the framework for a 'pinning down' 1 of justice through empirical inquiry. We illuminate its complexity through a study of light and its capture in photographs. In demonstrating the relationalities of mobilities and light we reveal the possibilities for urban justice and contribute to debates on mobility justice. We respond to storytelling as a utopian practice with 'narrative itself an intrinsically utopian expression' (Levitas 2013, xiv). We are interested here in storytelling in light, through photography, and acknowledge the myriad city stories and different angles of view, particularly in the night. Ours are tales of the less tangible social networks being illuminated, differently from infrastructural illumination. We draw inspiration from William H Whyte's $(1980,1988)$ The Street Life Project, his seminal photographic investigation of urban streets, which included time-lapse photography, interviews and direct observation of street life. We explicate the night-time in a busy (and designed) street space in the middle of a south coast UK city through a 24-hour ethnographic study of New Road, Brighton (Murray and Robertson 2016, 2017). This is a renowned exemplar of 'shared space', re-configured by Copenhagen-based urban designers Jan Gehl to re-prioritise urban space so that it can be used more justly by different people. Following Barthes (2000), we argue that photographs are mobilised in their evocation of feelings and it is in the feeling of urban space that possibilities for transformation are intimated.

We then, thirdly, offer up some possibilities, some suggestions of what might emerge through 'utopia as mobile method', based on an analysis of photographs that formed part of the data collected through our mobile ethnography. By studying the narratives of the street as they are captured and re-told through photography, we find that there are no exacting linear, modernist contours of flows, but that physical boundaries are disrupted, exploited and open up glimpses of non-linear practices. We might think that the urban night is less substantial, more transient and less tangible in the absence of daylight. But, even if fleetingly, illumination re-forms or re-imagines the surfaces and spaces at night; the intensity, depth and meaning of surface interactions are often full of drama, emotion and shifting proximities and intimacies. At night shadows are drawn, transforming the grain, texture, depth and contrast of surroundings, creating urban borders that can be likened to Sennett's (2006) 'territorial edges'. These edges, according to Sennett (2015), are potentially porous, open to social mixing. We also look to another edge, the 'boundary' between ethnographic and expressive photography (Edwards 1997), for the opening up of 'possibilities' (Lefebvre 1996).

\section{Mobilising (u)topia as method}

In her presentation of 'utopia as method', Levitas (2013, xi) sets out a manifesto for social research that seeks to 'provide a critical tool for exposing the limitations of the current policy discourses about economic growth and ecological sustainability'. For Levitas, utopia as method is about developing ideas about possible futures, whilst at the same time adopting a reflexive approach to 'the principles and practices of those futures' (xi). Although ambitious, the method is premised on the pursuit of 'a better way of being or of living' guiding us 'from existential and aesthetic concerns 
to the social and structural domain' (xiii). Importantly, it is multi-scalar - striving for change from the site of the individual to macro scale transformations of institutions and systems. Utopia as method includes archaeological, ontological and architectural elements. It is cognisant of 'the actual architecture, the physical infrastructure...' but sees the utopianism in these when they are 'open to changing intentions of people who use them' (Levitas 2013, 214). Hence whilst it is acknowledged that the progressive architectures of the 1960s and 1970s blocked certain flows, they also allowed different, new occupations to be protected. Levitas uses a different conceptual language from Olwig (2002), whose geographical perspective in moving beyond utopia and dystopia to 'topia', offers a reference to place, to the spatial. Pinder (2013) argues that although Levitas' focus is not on the urban, her utopia as method can be used in this context and its archaeological dimension can be likened to Lefebvre's excavation of the utopian in urban projects. For Lefebvre, utopianism went beyond macro politics towards imagining different futures based on a dialectical relationship of the possible and impossible. As Pinder $(2013,29)$ argues, Lefebvre's version of utopia as method underlies a critical urban theory that 'seeks to do more than record and describe urban worlds, that combines analysis with opening paths towards alternatives.' But it is more than a theory, for Lefebvre argued that going beyond the dialectic of possible and impossible means paying very close attention to the 'real', the quotidian experience of individuals (Coleman 2013).

Central concerns of mobilities research are exemplified in Lefebvre's open and optimistic analysis of urban transformations. Lefebvre was attentive to the non-linear, 'continuities as well as ruptures or relative discontinuities, in which the virtual enables examination of the realised...' (Pinder 2013, $33)$, thereby challenging blocks and barriers. Lefebvre's $(2003,17)$ focus on the lived allowed him to realise the possible in seeking to 'overcome or break through the obstacles that currently make it impossible'. He sought to overturn how the concept of utopia was understood, with a focus on the 'real' or 'concretised'. This requires, for urban scholars, imagining beyond what may seem possible in transforming urban space, 'in exploring and making real what currently seems impossible, unknown or out of our reach' (Chatterton 2010, 235 cited in Pinder 2013, 31). This is the 'concrete utopia' as opposed to 'abstract utopia', which Levitas $(2013,353)$ argues is 'compensatory rather than anticipatory'.

Lefebvre's utopia was forward thinking - of change - whilst looking back. It was about 'counteract[ing] the disaggregation of the modern city' of atomisation - 'art from life, theory from practice and work from play' (Levitas 2013, 356). For Lefebvre, utopia is about imagining a possible that 'positivism attempts to paint as impossible' (Levitas 2013, 356). This possibility, Lefebvre argued, can be achieved through 'transduction', a process of identifying problems and inventing alternatives and 'empirical observations' of reality as a 'bulwark against dissociative abstraction' (Lefebvre 1996 cited in Coleman 2013, 141). The ocularcentrism of architects and their focus on appearance rather than experience, according to Lefebvre, has led to them overlooking the 'the most successful places' as they are embodied rather than solely visual (Lefebvre 1996, 151 cited in Coleman 2013, 359). Lefebvre's view was that urbanism 'blocks a view of the horizon' $(2003,160)$, preventing 'thought from becoming a consideration of the possible, a reflection of the future' (Levitas 2013, 161). Instead, Lefebvre (1991) was concerned with the ways in which urban spaces are socially produced, which he understood through observation. He spent a significant amount of time observing the street. It is fertile ground for an analysis that can then be scaled up and illuminate possibilities from impossibilities. Observation of the urban street allows consideration of material and spatial concerns and how they interrelate to the social as they are practiced.

Utopia as method thus recognises the dominant ideological infusion of utopia but also its possibilities to challenge these ideologies; and this requires understanding the felt experience of urban spaces as determined through ethnographic investigation (Cunningham 2010). It is more than method - it is methodological in its scope - encompassing philosophy, theory and experimental method. Utopia as mobile method is rooted in utopian ideologies, theories of mobilities and methods that are mobile. In Lefebvrian terms, our research site is an example of experimentation and invention in the context of wider social and spatial conditions. Our mode of inquiry, although based on vision, is more than seeing and as such allows an exploration of possibilities. We look to night-time in a busy street space: New Road, Brighton. This is a street 
space designed to be 'inclusive' urban design, epitomising the designers envisioning of 'cities for people' (Gehl Architects 2010). It is a 'shared space', a transport engineering term for a street that has been stripped of the usual delineation of road and pavement. Instead the street becomes an open space in which pedestrians, cyclists, vehicle users and those who are not moving through the space but settling within it, have a more equitable access; they have more similar 'rights' to the space. New Road is itself based on a 'utopian' vision that, according to its architects, aims to create a 'ground floor' space to 'celebrate and amplify diversity' (Gehl Architects 2010), an imagination shared with the city's politicians and planners. The purpose of our research was to explore the space through a 24-hour mobile ethnographic study, and to interrogate possibilities, not only in the daytime, but also at night, when the street becomes striated with light and dark. It is perhaps the difficulty in visibly observing that prohibits close examination of night-time spaces, but the use of photography in producing images that can be more closely analysed opens up new opportunities for seeing beyond the shadows, for feeling as well as seeing and for drawing out the possibilities for spaces that are porous to a range of social and spatial practices, by a range of people. Hence, our utopia as mobile method seeks to avoid incomplete and atomistic accounts and to look to ways of feeling as well as ways of seeing. Here we use photographic methods not as visual windows to a 'truth' but as mediators of feeling that narrate our street space during the hours of darkness.

\section{Imagining utopian method: light and mobility}

Frederic Jameson (2005) sets out that utopias are predicated on what we know and can therefore imagine and that this depends on certain visual familiarity or 'likeness' even if then fragmented and re-assembled in various ways: it is essential to recognise what experience may be. Perhaps this is why the materiality of architectural utopias have such a strong connection as they represent imaginations in ways that are at least partially accessible. However, Lefebvre's critique of ocularcentrism, along with the Situationist's discussion about the commodification and reification of the image according to Debord's The Society of the Spectacle and Baudrillard on the ultimate simulacrum, contribute to our questioning of the ways in which power relations play a part in coopting social systems. This argument is closely related to the discussion in Edensor (2017) concerning power and control: the erasure of customs and control of illumination in order to normalise and control space and mobility. Edensor (2017) is concerned with how those with power forge the normative of everyday illuminated space now and how those without power push back by re-appropriating light.

Using the example of Haussmanisation in Paris in the nineteenth century and drawing from Schivelbusch (1988) on street lighting, Edensor (2017) shows how light has been used to spatially order and control urban populations. Haussman's large scale re-planning in Paris was publicised as bringing light and air to the slums, but an undeclared and more sinister intention was to deter social unrest, enabled by movement in the city, through illumination. The people of Paris, however, duly responded by destroying lanterns that lit the streets and thus re-establishing a 'wall of darkness...' (Schivelbusch 1988, 106 cited in Edensor 2017, 83) and disguising their subversive mobilities. Thus, although light is used by architects of urban space to maintain power relations in mobile space, it can also be used for resisting the pervading relations of power. The methodological questions then, are how to scrutinise the uneven deployment of light and its determining of urban mobilities and how does this offer up possibilities for transformation.

Interrogating the relationship between light and mobility through photography has a long history in social research. Eadweard Muybridge meticulously analysed the kinetics of humans and animals in an attempt to 'capture' the 'truth' of humans and non-human movement in photographic form (Cresswell, 2006). Much of the early sociological photography could be positioned as utopian. Early photographers, such as Thomson (1877) and Riis (1890) focused in on particular subjects in perpetuating a narrative of urban impoverishment, decay and squalor. These were visual observations of urban social life in London and New York respectively, that sought to invoke philanthropic and policy interventions in order to transform. Paradoxically, these photographers often immobilised their subjects, in an effort to represent the 'truth', for example through the use of 
flashlight photography. The subjects became transfixed in the glare of the flashlight so that the image became a manipulation of light and mobility. As Lalvani $(1996,66)$ argues they are 'forced to confront the camera's gaze: rigid frontality signified the bluntness and 'naturalness' of a culturally unsophisticated class'. Many of the early visual sociological projects photographed their subjects in close proximity, denying them their wider context. Photographic enquiry in utopia as method, as argued by urban scholars including Lefebvre (1991), demands zooming out as well as zooming in (Murray and Robertson 2017). Whyte's $(1980,1988)$ photographic investigations of New York did just this, using different methods to study street space at different scales and from different angles to capture a fuller narrative that encompasses wider 'possibilities'. Photography does more than capture mobility, it provides us with the opportunity to reflect and think critically on the proximities of imaginings and 'realities'. The juxtaposition and sequencing of photographs has the potential to provoke experiences, as a 'montage' of fragments contrast and collide in unexpected ways, mobilising critical enquiry and drawing attention to the space for viewing that is created between the determined and speculative (Rendell 2008, 78).

In Camera Lucida, Barthes (2000) conceptualises photography from the perspective of the observed and of the observer, rather than the photographer. This precedes other visual scholars, such as Rose (2016), who have determined a critical visual methodology that encompasses the different sites of the photographic image. Emmison and Smith $(2000,4)$ argue that visual sociology is about seeing rather than representing; that 'the reliance on 'the photograph' as a form of data in its own right has prevented visual researchers from discovering a more fundamental level of analysis'. As Emmison $(2004,246)$ suggests we 'think of the visual in terms of not only what the camera can record but what the eye can see'. Furthermore, Newbury (2011) contends that a visual scholarship should not focus on ways of seeing but 'ways of thinking'. Whilst maintaining caution in separating the eye and the mind and the potential privileging of text, he argues that the aesthetic qualities of visual images produce a set of complexities that require particular and careful engagement; that 'images are not ideas in disguise, but are themselves intellectual propositions' (Newbury 2011, 652).

Barthes (2000) argues that the nuanced interplay of mobility and immobility elevates photographs: 'It is as if the photograph always carries its referent with itself, both affected by the same amorous or funereal immobility, at the very heart of the moving world' (Barthes 2000, 5). Mobility and immobility are manifest in the 'studium' and the 'punctum'. The studium is the 'general, enthusiastic commitment' to the photograph, 'but without the acuity' (Barthes 2000, 26); it is the 'wide field of unconcerned desire, of various interest, of inconsequential taste', the 'vague, slippery, irresponsible interest' that engages with the photographer and allows some understand of their motives (Barthes 2000, 27). The punctum, on the other hand, is the 'sting' of the photograph: according to Barthes, 'the accident which pricks me (but also bruises me, is poignant to me)', punctuating the studium. The punctum, for Barthes (2000), is beyond coding, beyond 'naming' for: 'what I can name cannot really prick me'. Photographs may be, therefore, remised on a static image, but at the same time, they do what moving images cannot - they mobilise the mind in 'pensiveness' as we visit and revisit the same scene. Until there is a punctum, an evocation of feeling, 'the Photograph [is] a motionless image[...]the figures it represents[...]do not emerge, do not leave: they are anesthetized and fastened down, like butterflies' (Barthes 2000, 57).

Thus, photographs are more than ways of seeing, but ways of thinking and feeling, as they become mobilised. Through these mobilizations, they produce different sets of movements enabled by the capturing of light in particular ways. Photographs can be read, as social and spatial 'texts', not just once as they speed by like the fleeting visions of a moving image, but engaged with, digested and reflected upon. However, in urban and mobility studies, where there is photographic inquiry it is more often limited to one mode or another: the meticulous multi-angle approaches of Muybridge and Whyte or the aesthetic photography of urban cultural studies. This has created a methodological edge or 'boundary' (Edwards 1997) between expressive and ethnographic photography, which we set out to explore in more detail. Kroon $(2016,191)$ argues that a lack of methodological attention to different photographic traditions has led to a lack of communication of 'subjective and affective knowledge'. She suggests that urban visual scholars need to go beyond photographic image to a range of visual materials in order to understand the 
ways in which images evoke feelings. Through her study of the old downtown of Managua, Nicaragua, Kroon $(2016,191)$ suggests a move towards 'a practice-led visual study in which the researcher-generated expressive photography explores the "city-as-archive". Citing a number of studies that look at the space between artwork and ethnographic commentary, Kroon posits that expressive photography elicits sensory engagement: 'with its focus on details and fragments and moving in close to their subjects, it can help us tune into the complicated, affective experiences of the urban space' (Kroon 2016, 194). This becomes possible through a direct sensory interaction that brings the researcher closer to the subject. As such it becomes a 'credible visual method' in urban ethnography. Thus, understanding the differing angles of expressive and ethnographic photography and to gauge the extent to which we can move 'beyond the boundary' (Edwards 1997) between these approaches, to provide a place for expressive photography in ethnography (Pink 2007; Kroon 2016).

Urban night photography, we argue, presents a particular intellectual proposition, illustrated in, for example, the London Nights exhibition (Sparham 2018), which considers a number of ways of approaching the photography of urban spaces at night. The key curatorial themes are concerned with aesthetics, unsettling affects and the interactions of urban dwellers, all of which are useful ways of approaching our photographic material. Visual and social transformations are 'amplified in the night light, captivating the eye and heightening the senses... The eye adjusts...to read and engage....in this alternative nocturnal night....infinite opportunities arise.' (Sparham 2018, 9) The social opportunities and visual potential are mobilised in the illuminated city. The seen and unseen operational aspects and techniques of the illumination contribute to the intrigue. As we consider different techniques and practices, whether social documentary, portraiture or constructed imagery to provide insights into the life of a street at night.

Artist photographer Rut Blees Luxemburg has concentrated attention on the night, in order to show the everyday gritty reality of the changing city (Museum Crush 2017). In Luxembourg's six-minute film London/Winterreise (2013), the rhythm of columns and bins, repetition, contrasts of movement and stasis all combine to draw attention to textures that give clues and hints of narratives from different times; there is a thickness to the timeframe. Her photographs have been described as 'identifying that moment of communion when the search for a subject is over, and the numinous alter ego of [the city's] identity is briefly on display...the missing piece of time between witness and recollection' (Bracewell 1997, 9). The long exposures of Luxemburg's photographs capture the stasis and anticipation or memory. But her images are always devoid of actors, providing fragments that allude to epic stories, suggesting abandonment and a critique that the progressive desires of the modernist project have failed. This is accentuated when these arrestingly luminescent fine art images are placed in the gritty and neglected spaces of the city. Long and shorter exposures tell different stories. Just as there is a long history of sociological and documentary urban photography, so too the practice of expressive urban night photography is well established, in the work of renowned photographers such as Brassaï working in Paris in the twentieth century interwar period and the array of photographers on display in the exhibition London Nights (Sparham 2018).

We based our approach to photography in our mobile ethnography on an appreciation of both expressive and ethnographic genres for a diversity of approach. We looked differently at the images taken by the team of ethnographers who were collecting data in various forms - including photographically - and those taken by 'expressive photographers' - students of photography at the University of Brighton. Both were briefed in the same way:

Photographs of the entire bench and surrounding area should be taken at regular intervals during the research period and at least every 10 minutes. You must ensure that you ask people for their permission to be photographed. (from Sharing Urban Space: ethnography of a bench in New Road, Brighton. Briefing for researchers)

Hence the researchers and photographers were given a great deal of freedom in determining their method of photography and deciding on subject, scale, positioning, framing and so on. The photographs captured and created the illumination of the street space and the mobilities and 
immobilities within it as well as of the 'ethnographic image'. We set out then to read the photographs from our 24-hour study of New Road, based on our 'utopia as [mobile] method' that sought to visibilise the 'possibilities' of the urban night through feeling the images. We looked to the boundaries, the edges, to the shadowy and dark spaces in the photographs.

\section{Illuminated mobilities: possibilities at the boundary}

Edensor $(2017,84)$ discusses the relationship between light and senses and the control of light as an 'ordering of the senses' to enable 'functioning, rational and moral subject'. For him, 'darkness provides a cloak for alternative and oppositional practices that temporally disorganise space, contributing to an ongoing contestation between ordering and disordering impulses'. He refers to Shaw's work on particular cold colour palates of illumination used to move on night-clubbers, to stop people lingering. However, these schemes are not necessarily evenly spread, either between centre and periphery of a city or between wealthier and less wealthy neighbourhoods (Edensor 2017) and, to take this further, the opportunities to re-imagine and practice city spaces differently is also controlled by planning decisions and access to funding. This leads to inequalities as the potential for illumination to reveal and to disrupt the linear processes and practices of urban spaces is limited or denied. An unevenness or discontinuity of night-time citizenship emerges.

In the introduction we discussed the boundaries or edges of urban space as spaces of 'porosity' (Sennett 2006) and suggested a parallel to Edwards' call for moving beyond the boundary of expressive and 'realist' photography, where realist photography is considered to have strong indexical relations to 'real' as opposed to 'aesthetics and subjective interpretations of the photographer' but the two are not incompatible and we look 'beyond the Boundary'. We argue that by attending to the aspects revealed in different ways by different traditions, in dispelling this boundary we can reveal others, more palpable that point towards, or suggest, the unevenness of mobile spaces as well as their possibilities. In Night Haunts, Sandhu (2010) proposes the city as 'part docudrama, part carnival of the grotesque', but our investigation tells us that the street at night is less a 'carnival of the grotesque' and more a space of multiple and complex interactions in which marginalisation and exclusion are themselves uneven. Our photographic analysis shows that it is a docudrama of seemingly everyday and routine practices that highlight the mundanities of life in an urban street but, when read from a utopia as method perspective illuminate the varying possibilities that emerge in illumination and in shadow.

Our first set of photographs (Figure 1) are taken by ethnographic researchers. The photographs could be said to be aimed at 'documenting' the ordinary. Visual sociologists Becker (1995) and Harper (2012) both acknowledge the overlaps between documentary photography and its production of certain truths, and this is a particular type of documentation. Hence, the photographs are less attentive to style and aesthetic; they are often blurred and ill-framed but nevertheless capture something different. They are arguably not so pleasing to the eye and do not immediately evoke a strong emotional response. But at the same time, the photographers are skilled in reading the scene. They are not 'amateurs' reproducing social norms (Evans 1999) but are seeing with, in this case, a visual sociological lens documenting the scene as social investigators in a similar way to documentary photographers. As photographic historian Rosenblum $(1984,341)$ argues:

'images in the documentary style combine lucid pictorial organisation with an oftenpassionate commitment to humanistic values - to ideals of dignity, the right to decent conditions of living and work, to truthfulness'.

'While the social documentary photographer is neither a mere recorder nor an artist for art's sake, his reports are often brilliant technically and highly artistic'. 
This series of photographs is not necessarily brilliantly technical or highly artistic - but at the same time there is attention to detail of social scene that makes it both technical and artistic. The artistry is reinforced in the critical reading of the photographs - through a continuum of ethnographic interrogation. The editorial sequencing of the series also contributes to many possible readings this sequence is our selection and tells a particular story. It is only through looking closely that figures emerge from the darkness - it takes time to adjust to the light. It is also only in the series of photographs, like Whyte's (1980) time lapse photographs of New York, that we see movement in the space. We are drawn to one figure, who evokes a particular emotional response - the punctum - and then in each of the photographs as our eyes search for him amongst the other figures. He moves to and fro along the bench throughout the night. This series of photographs show the early hours of the morning - from 01.29 to 04.00 . It is at first difficult to spot the man - he is black and even though it is summertime, he wears a dark coat and woollen hat. But at the same time he stands out. We know that he is a 'rough sleeper' through observation and interviews, but we might deduce this anyway from his unseasonal dress. We trace the man through the photographs. He moves from the right-hand side of the frame to its centre, but he is always on the edge, sometimes looking into the space and sometimes talking to others. In the final image (at 04.00) we witness a change in practice - we can see from the colour of the sky that it is dawn and the space is gradually lightening. The bench and the trees behind are dark but in front of the bench there is just enough light to see the man picking up rubbish. It is not a performance; the mundanity of his actions suggest that this is a regular thing for him. The rubbish is clearly visible in all the photographs as light reflects off the shiny surfaces of metal and plastic. Further, transitions and transformations in the 'twilight' of dusk and dawn take place in the temporal boundaries and thresholds that hold the most evocative emotional senses in the liminal time between topias. In this respect we can see that city spaces captured at dawn and dusk have a very particular impact as the relationships are less fixed, transitions and transformations are imminent and feelings of despair and hope may be heightened.

There is a particular purpose in the work of the 'ethnographic photographers' to, as Barthes (2000) suggests, capture the interplay of mobility and immobility. It is this aspect of urban space that we are concerned with here: the spaces of slowing down, stopping, moving between and moving through. At the same time, the detail in this series is unintentional but hard-hitting in its depth of meaning. The intention is with the reading of the photographs - looking to elicit and elucidate the layers of meaning, in combination with the other aspects of the ethnographic data. The unintentional detail of the ethnographic photographer reveals the social and spatial boundaries of the space, and also the possibilities of social practices that might be unexpected. The subject in the image appears to be an active social agent in moving and settling in the space, transforming the urban street. We can see this in particular when we cross reference to ethnographic notes and drawings. One of the 'expressive photographers' was in the space at the same time, but did not capture this series of photographs. As they set up the more aesthetically intentional image, they moved on to capture another, different scene. Here our subject is not intentionally being photographed but nevertheless he is revealed. If these scenes were read based on a utopian/dystopian dualism they might be consider dystopian. Here we reveal Lefebvre's (1996) possibilities through everyday practice, as empirically observed.

\section{Figure 2: Dancers}

The 'expressive photographer' seeks out the interesting, different, out of the ordinary aspects of the street as in the photograph of people dancing in the street (Figure 2). They are re-making the street space, playing with the light, appropriating the part of the street that is usually for vehicles. We ask ourselves what this 'art' is capturing of the mobile interactions on New Road. Looking to sociologist Georg Simmel's argument that there is 'more truth in art' and Frisby's (1981) reading of Simmel's work as 'sociological impressionism', it could be argued that the photographer as artist is creating an aesthetic in order to produce a response, to make audiences feel the space. The photographer waits for the right moment, with the right framing, the right lighting to create a photograph that will impress upon its reader, make them feel, which becomes the basis of their photographic intentionality. The feelings here might relate to the vibrancy of the street, the different 
people using and enjoying it, groups of young people taking shared space at its word and taking ownership in a way that appears not grotesque but acceptable. There is an abruptness in boundaries and thresholds of urban night illumination that does not allow for lengthy attuning of our senses and while darkness releases a greater interplay between the senses this potential to gradually, progressively 'make sense' of space is speeded up in illuminated spaces so that progressing into and through urban spaces at night necessitates a more rapid assessment of the more contained space. We can start to see that illuminated urban spaces provide the context for progressive, utopian imaginings while at the same time providing the means to recognise the contrasts and dystopian.

Scenic illusion is made possible at night through illumination - crafted, staged, designed, practiced. The (often invisible) devices of illumination have the effect of appearing to be a unifying 'control' from above and beyond. If street lighting has become an almost entirely technical matter (Edensor 2017, 101) that can be measured then capturing through photography becomes almost impossible to take at face value as it is always contingent on the photographer's position, physically, aesthetically and politically and thus producing creative output that holds an assemblage of approaches that are made visible through understanding and control of techniques. The photograph of the dancers is taken by a photographer. The brightness of the light is amplified and filters have been used to warm the tones, reminiscent of Rut Blees Luxembourg's night-time shots. It is staged in a deliberate, intentional way. The photograph captures more than a moment; there is a clear suggestion of the recent past and imminent future, the continuity and flow of dancing is familiar and the blurring of movements from the length of exposure draws attention to an extended duration and speed.

\section{Figure 3: Vivid and phantasmagoric taxis}

The contrast between ethnographic and expressive photography is foregrounded in Figure 3. - two photographs from a similar viewpoint and angle but taken by different photographers. The first photograph of a taxi is taken by an ethnographer and the second by a photographer. If the difference between expressive and ethnographic is considered to be premised around the evocation of feeling then this becomes blurred here. Both have a particular emotional engagement. Our punctum in the first is the women, and in particular the women on the right, who have an air of nonchalance that suggests an indifference to the taxi moving by within a meter of them. The photo evokes a sense of freedom - perhaps more so in our reading as we are struck by the number of women in this photograph. Looking back over our photographs we realise that they are mostly of men, reflecting the ethnographic observations and fieldnotes. In London Nights, the absence of women on the other side of the camera, on the other hand is palpable, powerfully exemplified in Alexis Hunter's Dialogue with a rapist (1978).

The taxi is moving slowly - the women are involved in conversation and appear to be at ease in the space. Looking more closely we can see evidence of our research - one of our photographers and her tripod. Musicians are playing but no one is listening, perhaps distracted by the photographer. The bright lights at the end of the street are clearly visible - they appear to be pulling people towards them, out of the space. The photograph is of mobility and immobility - some people in motion and others incongruously static. One of the women's dresses appears to be reflected on the street surface - but it is in fact the light from the rear light of the taxi. The synergy between these strips of colour emplaces the women - it is a temporary or fleeting emplacement. The second photograph is a longer exposure, again of a taxi moving down the street, our punctum being the blurred image of the vehicle. The scene has been cropped to highlight the phantasmagoric taxi, which appears to float above the street. It looks to be streaked with neon light. It appears to move at high speed, a trick of the light. The overexposed images of the people walking produce a ghosted feeling of speed and movement through. The taxi becomes a less tangible obstacle - we can literally see through to the simultaneous possibilities beyond, behind and in the same place. What we know to be a solid material object is also less of a block. 
At night, the shadows of street corners can be places of alternative social practices or of practices that are less seen suddenly, rudely illuminated by car headlights - sometimes through active surveillance, sometimes not. The lighting is more often purposeful - illuminating for necessity, for example the streetlights lighting up the path for both material and perceived safety. Safety has long been the rationale for providing increased surveillance and scrutiny of activities; through the overarching lighting schemes that are installed in cities it is possible to read an authoritarian approach as to what is 'better for' us: 'illumination always materializes power' (Edensor 2017, 81). Figure 4, another photograph taken by the same photographer as the second photograph in figure 3 , depicts a re-appropriation of light in response to the authoritarian illumination of vehicle headlights. It is less staged, responsive. From the drawings and notes made as part of our 24-hour study we know the time and circumstances around the photograph: this is an image of at least three acts. It can be viewed as a series of fragments that come together as a montage: the musician, the people obstructing the van and the older man on the right-hand side who appears separate again. The drama is accentuated by the strong and low-level headlights, from the van and from another unseen vehicle behind. The partial silhouette of the women in front of the van suggests a self-consciousness of their performance. The quality and direction of light has dramatically transformed and allowed the way the space is used. Here we are drawn to the activities that are illuminated and the boundaries of light and less light are evident but not because they are any more or less utopian or dystopian as we have shown that there are possibilities in both. Attitudes towards dwelling in New Road are diverse and contingent on many things such as state of mind, ability, identity, alone or together, sense of purpose and direction. These many different experiences also contribute to the fluctuations - so as attitudes are captured and documented, how they are represented alters our readings according to the framing of the photographer. Creative photographic tactics are affected by the quality of light, how it frames and reveals a subject but also how the context is perceived. Here the light is implicated in the subversive practices of the street. As Levitas $(2013,214)$ suggests, spaces are to be 'sufficiently flexible for human artisans to sculpt their own collective futures therein' in order to be utopian.

\section{Conclusion}

Our utopia as mobile method approach is predicated on producing knowledge of injustice, alongside possibilities for transformation. In Expulsions, Sassen (2014) asserts that cities are witnessing an unprecedented and uneven escalation of 'poverty and injustice'. Although Sassen focuses on macro level processes, this escalation is evident also at the micro level, in the mobile spaces of city streets. Arguably this requires 'genuine holistic thinking about possible futures', a 'utopia as method' (Levitas 2013, xi). We respond by demonstrating how utopia as method might inform studies of mobility justice. Rather than draw particular conclusions about justice in street space, we are rather suggesting, like Lefebvre, that urban street space offers possibilities for a more just mobile space. We have looked at how light and mobility may be expressed and felt in urban spaces through photography and how an assembly of the positions of photographer and viewer of photographic images opens up and mobilises enquiry into the tangible and less tangible boundaries between the conditions of illumination at night and power relations of urban occupations. Through the development of our investigation we have established that Levitas' suggestion of a porous utopia allows us to open up utopia as method in interrogating the porosity of street spaces and thereby revealing justice and injustice.

It is the emergence of the possibilities of the street space that precipitate this. In part we are responding to Sheller's (2018) critique in that we demonstrate that there is instability in both time and place of the borders and boundaries that may contain and define injustices - they are seen and unseen and we have opened up the possibilities by illuminating the largely unseen. The photographs implies some things about the politics of scale and speed: the juxtapositions of 
vehicles and bodies, their acceleration and slowness. The lighting of windows also suggests nearby interior spaces, which juxtapose more 'private' space with the public space of the street, and the street benches might evoke a 'room', set against the green wall of trees (and the night sky) are suggestive of a larger scale, almost 'outside' of nature and a dark forest beyond the human illuminated space. Hence our 'utopian' visual analysis of this streetscape hints at the many other scales - and many kinds and possibilities of mobilities -- that are present here.

We take Edensor's thinking on light and darkness and the impact of infrastructural and systemic power relations further in seeking possibilities in the shadows of the night-time street. In the dark spaces the potential is open and infinite. Through using photography as a literal and metaphorical lens we have been able to open up and examine the stories of city spaces in new and productive ways in identifying how injustices are produced and co-produced in unexpected and previously under scrutinised ways. Photography expands the possible imaginings that utopian thinking demands. The unevenness of urban citizenship has become more clearly defined and our focus has brought a new way to mobilise utopias. Visual landscapes are designed more effectively at night; their characteristics and prominence are partly pre-determined but also created by those who occupy and those who view them. Our analysis of the borders and boundaries that are not only prescribed but also created has moved our understanding of urban mobility justices. Our focus on the illumination of urban nightscapes has allowed us to concentrate on the relationship between performance and attention and we have looked closely at how power is used to attract our attention. Our analysis suggests that a close empirical analysis of urban street spaces in myriad urban contexts have much to contribute to debates on urban and mobility justice.

\section{Endnotes}

${ }^{1}$ Critiques of Lefebvre's 'right to the city' have pointed to the difficulty in 'pinning down' the theory (Attoh 2011 and MacLeod and McFarlane 2014).

2 The van licence plate has been blurred out for the purpose of anonymity

\section{References}

Attoh, K.A. 2011. "What kind of right is the right to the city?" Progress in human geography 35 (5): 669-685.

\section{Barthes, R. 1982. Camera Lucida: reflections on photography. London: Cape}

Becker H.S., 1995. "Visual sociology, documentary photography, and photojournalism: It's (almost) all a matter of context." Visual Sociology 10 (1-2): 5-14.

Bracewell, M. and RBL, 1997, London - A Modern Project. London: Black Dog.

Coleman, N. 2013. "Utopian Prospect of Henri Lefebvre." Space and Culture 16 (3): 349-363.

Cresswell, T. 2006. On the move. London: Routledge.

Cubitt, S. 2013. "Electric Light and Electricity." Theory, Culture and Society 30 (7-8): 309-23

Cunningham, F. 2010. "Triangulating utopia: Benjamin, Lefebvre, Tafuri." City 14 (3): 268-277.

Edensor, T. 2017. From Light to Dark: Daylight, Illumination and Gloom. Minneapolis/London: University of Minnesota Press.

Edwards, E. 1999. "Beyond the boundary: a consideration of the expressive in photography and anthropology". In Visual anthropology, edited by M. Banks, and H. Morphy. London: Yale University press.

Emmison, M. 2004. "The conceptualisation and analysis of qualitative research". In Qualitative research: theory, method and practice, edited by D. Silverman. London: Sage.

Emmison, M. and Smith, P. 2000. Researching the visual: images, objects, contexts and interactions in social. London: Sage.

Harper D.A. 2012. Visual sociology, London: Routledge. 
Gehl Architects. 2010. Paving the way for city change. http://gehlarchitects.com/cases/new-roadbrighton-uk/.

Jameson, F. 2005. Utopia Now in Archaeologies of the Future: The Desire Called Utopia and Other Science Fictions. London: Verso.

Kroon, A. 2016. "The ruins of Managua vieja: the use of expressive photography in urban ethnography." Visual Studies, 31 (3): 191-205.

Lalvani, S.1996. "Photography, Vision, and the Production of Modern Bodies." Utopian Studies 7 (2): $282-284$.

Lefebvre, H. (2003/1970) The urban revolution. Minneapolis: University of Minnesota Press.

Lefebvre, H. 1996/1968. "The right to the city". In Writings on cities, edited by E. Kofman and E. Lebas Oxford, England: Blackwell.

Levitas, R. 2013. Utopia as Method: the imaginary reconstitution of society. London: Palgrave Macmillan

Murray, L. and Robertson, S. 2016. Sharing mobile space across generations. In Intergenerational mobilities, edited by L. Murray and S. Robertson. London: Routledge.

Murray, L. and Robertson, S. 2017. "Drawing mobile shared spaces", In Mobilising design, edited by P. Pinch, S. Reimer and J. Spinney. London: Routledge.

Newbury, D. 2011. "Making Arguments with Images: Visual Scholarship and Academic Publishing." In The SAGE Handbook of Visual Research Methods, edited by E. Margolis and L. Pauwels, 651664. London: SAGE.

Olwig, K. R. 2002. "Landscape, Place, and the State of Progress" in Progress: Geographical Essays, edited by R. D. Sack. Baltimore: The Johns Hopkins University Press.

Pinder, D. 2013. "Reconstituting the Possible: Lefebvre, Utopia and the Urban Question" International Journal of Urban and Regional Research, 39 (1): 28-45.

Pink, S. 2007. Doing Visual Ethnography. 2nd ed. London: Sage.

Riis, Jacob A. 1890. How the other half lives: Studies among the tenements of New York. New York: Charles Scribner's Sons: Trow's Printing and bookbinding company.

Rose, G. 2016. Visual methodologies: an introduction to the interpretation of visual materials (second edition). London: Sage.

Rosenblum, N. 1984. A World History Of Photography. New York: Abbeville Press.

Sack, R. D., (ed.) 2002. Progress: Geographical Essays. Baltimore: The Johns Hopkins University Press, .

Sandhu, S. 2010. Night Haunts: A Journey Through the London Night. London: Verso.

Schivelbusch, W. 1988. Disenchanted night: The industrialisation of light in the nineteenth century Oxford: Blackwell.

Sennett, R. 1990. The Conscience of the Eye. New York: W.W. Norton.

Sennett, R. 2006. The open city, Newspaper essay, Urban Age, London: London School of Economics. Accessed at:

http://downloads.Isecities.net/0_downloads/Berlin_Richard_Sennett_2006-The_Open_City.pdf on 13 July 2015.

Sennett, R. 2015. The world wants more 'porous' cities - so why don't we build them? The Guardian 27 Nov 2015.

Sheller, M. 2018. Mobility justice: the politics of movement in the age of extremes. London/New York: Verso.

Sparham, A. 2018. London Nights. London: Hoxton Mini Press. 
Thomson, J. and Smith, A. 1877 Street Life in London. London: Sampson Low, Marston, Searle and Rivington.

Wagar, W. W. 1991. "J. G. Ballard and the Transvaluation of Utopia." Science Fiction Studies 18 (1): 53-70.

Whyte, W.H. 1988. City: Rediscovering the centre. University of Pennsylvania Press.

Whyte, W.H. 1980. The Social Life of Small Urban Spaces. New York: Project for small spaces. 